\title{
Rope Walker, A True Story
}

On a warm, still afternoon in 1884, the citizens of Corsicana, Texas, gathered in the center of town for Trades Day. ${ }^{\mathrm{I}}$ Merchants from Navarro and nearby counties set up displays of their goods along Beaton Street, and a crowd came out to take advantage of the bargains and to enjoy the food-baked, fried, and barbecued-offered from stalls and shop windows. Normally a quiet stop along the Houston and Texas Central Railroad, Corsicana came alive for a brief time to celebrate its commercial success and, just as importantly, to break the monotony of life in an East Texas town of only a few thousand people.

Beaton Street was bustling with visitors - itinerant peddlers, shopkeepers from nearby towns, wholesalers in to drum up business with local stores, farmers and their families come to see the newest implements and to stock up on supplies. In that crowd the stranger could have blended in easily. Even the wooden peg leg where his right calf and foot had once been would not have drawn attention among people so accustomed to the sight of Confederate war veterans. His intention, however, was not to go unnoticed.

Later tellers of the story disagree on whether he was working for someone wishing to make a lasting advertising impression or had dreamed up the stunt on his own. Some have suggested that he was a former circus performer plying the only trade he knew for scattered nickels and dimes from the crowd. Few disagree, though, on the particulars of what he did. 
As the people moved among the stalls, a heavy rope, one end securely tied to a rooftop, flew overhead to another rooftop across the intersection with Collin Street. They watched as the stranger came down from the first building, hobbled across the street, vanished into the second building, and reappeared on the roof to pull the line taut and tie it off. As they looked curiously up at him, he stepped back from the edge of the roof, out of their view. After a few dramatic moments, he reappeared, brandishing a pole several feet long. A cast-iron cookstove was attached firmly to his back with leather straps. Struggling only a little under the weight of the stove, the stranger stepped to the end of the roof, the balancing pole stretched out away from him on either side. He had tied his trouser legs over his knees, revealing the wooden leg, which he slid carefully out onto the line. People in the crowd saw that the bottom of the peg was notched to fit snugly over the rope.

Pushing the peg leg out before him, he followed with his good foot, stood a moment to secure his balance on the rope, waggled the pole a bitfor dramatic effect, surely-then slid the peg forward another step. The crowd fell to a tense hush and quickly cleared a swath below him as if rushing from a fire-far enough for safety but still close enough to watch. They stared upward as he worked his way along the rope, his face marked with intense concentration, his back straining forward under the weight of the stove. Even from two stories down, they could hear his strong and deliberate breathing, which settled into a mechanical pattern with the shifting of his weight and the inching of his body_slide the peg, step the foot-over the middle of the street.

He had his first trouble where the rope reached its lowest point and began its slight uphill incline toward home. He tipped a bit to one side, the crowd gasped, but he righted himself easily. With the next step he made another sideslip, dipping the pole opposite to recover his balance. The stove on his back gave him an unnatural inertia and he overcompensated, pulling too hard against the fall. Leaning more heavily now, he flung his shoulders again to the opposite side, the pole flailing uselessly in his hands, the quivering of his legs giving the rope first a barely controlled then a violent oscillation. He rode it there for a moment, then tumbled from the line. As the crowd watched in horror, he landed in a heap under the stove, a cloud of dust rising around him.

Someone confirmed that he was breathing, but barely. They carefully unstrapped the stove from his body and the strongest among them pushed it aside. Someone hoisted him over a shoulder and carried him to a nearby 
hotel, where they laid him in a bed and called for the town physician. Dr. J. T. Gulick arrived quickly and found the stranger hovering on the edge of consciousness. Gulick asked the stranger his name but got no response. A brief examination showed that death was imminent. Unsure if the stranger could even understand, the doctor gently told him the bad news and asked if he wanted a preacher. The cloudy eyes momentarily cleared, and the stranger said yes, please, he was a Methodist. The doctor sent for Methodist minister Abe Mulkey, who in later years became a famous evangelist.

Mulkey arrived and asked the man his name but got no response. He began to pray quietly over the bedside. Before he could get far, however, the stranger awoke, caught the minister's gaze, and whispered that, forgive him, he was not, in fact, a Methodist. He was a Jew, and could he please talk to a rabbi?

Like many Texas towns, Corsicana had a Jewish population, as many as three hundred by some counts, but they had no synagogue and no rabbi. Mulkey sent instead for a prominent merchant, a leader of the Jewish community. When the merchant arrived, he took Mulkey's chair at the bedside. The stranger was now very near death, and the two had only a moment to pray together-long enough for the man's flawless Hebrew to convince the merchant that he was undoubtedly Jewish — before the stranger died, his name still unknown.

Though without a synagogue, the Jews of Corsicana had organized themselves into an informal congregation, and they had set aside a piece of ground nine years earlier for a Jewish cemetery with a low fence around it to separate it from the non-Jewish graves nearby. They resolved that this was the only fitting place to lay the stranger to rest. They took up a collection, purchased a plain headstone, and engraved it with the simple epitaph "Rope Walker." It is there to this day in the Hebrew Cemetery in Corsicana, a reminder that in life, and perhaps especially in Texas, there is no greater virtue than balance. 
THIS PAGE INTENTIONALLY LEFT BLANK 